\title{
Normal variations in blood constituents
}

By I. D. P. Wootton, Department of Chemical Pathology, Postgraduate Medical School, London, W.12

The greater part of the work of the chemical pathologist comprises the analysis of blood or other body fluids and the interpretation of the results obtained. In order to distinguish abnormalities, it is essential to have an accurate knowledge of the range of normal variation, and a considerable amount of work in this field has been done. There are also interesting differences in the incidence of certain diseases in different populations, notably of certain malignant and degenerative diseases. The possibility that these diseases have a metabolic origin has led to much survey work on the levels of blood constituents in different countries.

\section{Overall variability}

If blood samples are taken from a group of normal people and the concentration of some blood constituent is determined in each sample, it is found that the results fall within a certain range of values. The distribution of the results has been studied by Wootton, King \& Smith (I95r). They studied about eighty normal adults aged 20-50 (see also King \& Wootton, 1956). Some of the resulting distributions were symmetrical and could be fitted with a Gaussian curve, but roughly half the distributions were positively skewed and were fitted with a log-normal distribution of the type that has frequently been found appropriate to biological data (Gaddum, I 945 $a, b$ ). Table I shows the type of distribution that has been found appropriate for each of the constituents studied, and includes data drawn from Pryce (I 960). It should be noted, however, that there is not complete agreement on this point: for instance, Josephson \& Dahlberg (1952) found a normal distribution for serum potassium.

Table $\mathrm{x}$. Types of distribution fitted to data obtained during surveys of normal values of blood constituents

\begin{tabular}{cll} 
Sample & \multicolumn{1}{c}{ Constituent } & Distribution type \\
Whole blood & Urea & Log-normal \\
& Non-protein nitrogen & Log-normal \\
& Glucose & Normal \\
Haemoglobin & Normal \\
& Sodium & Normal \\
& Potassium & Log-normal \\
& Calcium & Normal \\
Magnesium & Normal \\
& Chloride & Normal \\
& Bicarbonate & Normal \\
& Inorganic phosphate & Normal \\
& Protein & Normal \\
& Bilirubin & Log-normal \\
& Cholesterol & Log-normal \\
& Alkaline phosphatase & Log-normal \\
& Acid phosphatase & Log-normal \\
& Amylase & Log-normal \\
& Iron & Normal \\
& Haemoglobin & Normal
\end{tabular}




\section{Causes of variability}

Fawcett \& Wynn (1956) studied the serum content of sodium, potassium, chloride, bicarbonate and protein in a series of normal people who were examined on a number of occasions. They showed that, with the exception of sodium concentration, there was less individual variation between the results for an individual on different occasions than between those for different individuals; thus each individual tended to have a characteristic pattern of electrolyte concentrations. Similar results for other constituents, especially serum cholesterol, have been noted by other workers. For this reason it is convenient to make a distinction between the factors affecting blood constituents which are characteristic of an individual and other more physiological factors which apply to the circumstances of the analysis.

Individual variability. One of the most fundamental ways of classifying human individuals is by age and sex. Changes during the first few hours or days of life are not well known but there has been a considerable amount of work done recently on this subject (W. W. Payne, 1962, personal communication). The changes in childhood are better known, and are particularly well marked in those components of the blood which are concerned with ossification. Plasma alkaline phosphatase in the adult is normally present at a concentration of $3^{-1} 3$ King-Armstrong units/100 $\mathrm{ml}$. During childhood the level is often almost twice this amount. Serum inorganic phosphate at age of I year is about $5 \mathrm{mg} / 100 \mathrm{ml}$. The level falls to the adult value of $3.5 \mathrm{mg} / 100 \mathrm{ml}$ by about age 25. Winters, Graham, Williams, McFalls \& Burnett (1958) fitted their normal results with a regression line of the type

$$
\log \text { serum phosphorus }=\mathrm{a}-\mathrm{b} x+\mathrm{c} x^{2}+\mathrm{d} \log x,
$$

where $x$ is the age in years. They were also able to demonstrate a significant difference between the equations relating to normal males and normal females. In adults, Keys, Mickelsen, Miller, Hayes \& Todd (1950) found no sex difference in serum cholesterol. However, they found important changes in the serum cholesterol level with age. Between the ages of 17 and 60 years, the serum cholesterol rose by about $75 \mathrm{mg} / \mathrm{r} 00 \mathrm{ml}$ ('Table 2). In older people it tended to fall again and, since there is a known relation between the serum cholesterol level and the incidence of coronary infarction, this fall may have been partly due to the selection of people with low serum cholesterol values. Similar results have also been reported by Kornerup (1950).

Table 2. Changes in mean level of serum cholesterol with age

(From data of Keys et al. 1950)

$\begin{array}{cc}\begin{array}{c}\text { Age } \\ \text { (years) }\end{array} & \begin{array}{c}\text { Mean serum cholesterol conten } \\ (\mathrm{mg} / \mathrm{I} \text { oo ml) }\end{array} \\ 17-25 & 177 \\ 23-27 & 184 \\ 25-30 & 192 \\ 28-32 & 194 \\ 30-45 & 210 \\ 45^{-55} & 248 \\ 50-60 & 251 \\ 60-70 & 226\end{array}$


There are important sex differences in the level of circulating haemoglobin. Pryce (1960) collected data on normal haemoglobin levels from a number of large surveys and has shown that the mean haemoglobin level in men was consistently about $14.5 \mathrm{~g} / 100 \mathrm{ml}$ and in women about $\mathrm{I} \cdot 5 \mathrm{~g}$ lower. Only in the largest survey was it possible to demonstrate a small change in haemoglobin level with age; there was a small but definite increase with age in females and a corresponding decrease in males. Fawcett \& Wynn (1956) noticed that serum contents of sodium, chloride and bicarbonate were significantly lower in women as compared with men, the difference being about $\mathrm{I}-\mathrm{I} \cdot 5 \mathrm{~m}$-equiv./1. By contrast, the serum contents of potassium and total protein were not significantly different in the two sexes. Similar sex differences in these constituents were also reported by Hald, Heinsen \& Peters (1947). There are a number of other differences in the mean levels of blood constituents between men and women. For serum creatinine the difference is $0.2 \mathrm{mg} /$ $100 \mathrm{ml}$; for serum uric acid, I $\mathrm{mg} / 100 \mathrm{ml}$; for serum iron, $20 \mu \mathrm{g} / \mathrm{I} 00 \mathrm{ml}$ and for plasma citric acid, $0.2 \mathrm{mg} / \mathrm{I} 00 \mathrm{ml}$ (Howland, Zucker \& Clifton, I957), the higher levels being shown by men. On the other hand, the content of plasma copper is about $10 \mu \mathrm{g} / 100 \mathrm{ml}$ higher in women.

A number of genetically determined diseases are now known and the effect of gene dosage on the plasma levels of some constituents can be studied. Scott ( 1960 ) has determined the diphosphopyridine nucleotide diaphorase in the red cells of populations with hereditary methaemoglobinaemia. This disease occurs in Alaskan Eskimos and Indians and the affected cases show an almost complete absence of this enzyme in the red cells. In fourteen patients studied by Scott, the mean value for red cell diaphorase was 0.9 enzyme units. Children from the same population born to normal parents and who therefore did not carry the gene, had a mean value of 45 units. Parents of methaemoglobinaemic children are presumed to carry a single gene; thirteen of them were studied and found to have a red-cell enzyme level of 22 units with a range of $15-28$. Familial hypophosphataemia is a type of vitamin Dresistant rickets. It is probably sex-linked but is definitely caused by a dominant gene. In a survey by Winters et al. (1958), relatives of affected persons had serum phosphate values which were significantly low, i.e. falling outside the normal mean value for the age minus $2 \frac{1}{2}$ standard deviations. These people were presumed to be carrying the gene and many had affected children, but they themselves were often clinically normal.

Since the presence of a definite gene has been shown to be important in determining the blood level of some constituents, it might be expected that there could be differences between races. The difficulty is to disentangle the racial differences from associated differences in diet, exercise and social status. The mean serum cholesterol levels of Bantu, Coloured and European inhabitants of the Cape peninsula are respectively $\mathrm{I} 66,204$ and $234 \mathrm{mg} / 100 \mathrm{ml}$ (Bronte-Stewart, Keys \& Brock, 1955). These differences in serum cholesterol are reflected in the mortality rate from ischaemic heart disease in the three populations. However, the dietary fat intakes also vary widely, from $17 \%$ of the total calorie intake for the Bantu to $25 \%$ and $37 \%$ for the Coloured and Europeans. Furthermore, Keys and his co-workers (Keys, 
Kimura, Kusukawa, Bronte-Stewart, Larsen \& Keys, I958; Keys, 1956) have demonstrated differences in the incidence of ischaemic heart disease between rich and poor in both England and Spain and similarly between the incidence in Japan and among Japanese emigrants to the United States. Karvonen, Pekkarinen, Metsala \& Rantanen (196I) studied lumberjacks in Finland. Their mean serum cholesterol levels were of the high order associated with Western civilized man and closely matched those of sedentary workers living nearby. However, the lumberjacks ate a diet with the very high fat content of 200--250 g/day, and it was suggested that their serum cholesterol levels would have been even higher but for their hard physical labour. Moreover, Keys, Karvonen \& Fidanza (1958) demonstrated a difference between the serum cholesterol levels of East and West Finland, the inhabitants of East Finland having serum cholesterol levels of about $10-20 \mathrm{mg} / 100 \mathrm{ml}$ higher than those of West Finland. By classifying their subjects with respect to their birthplace, Keys et al. were able to eliminate the possibility that these differences were hereditary.

Physiological variations. The effect of diet on serum cholesterol values has been intensively studied since the amount and quality of the dietary fat was found to have such a profound effect on the serum cholesterol (see Bronte-Stewart, 1961). In spite of occasional inconsistent findings, it now seems clear that the level of serum cholesterol in the normal person can be reduced, on an isocaloric diet, if a proportion of the animal fat is replaced by unsaturated vegetable fat. Keys, Anderson \& Grande (I957) claim that the relation is extremely precise and have fitted their data with a regression line of the form

$\triangle$ cholesterol $=2 \cdot 74 \triangle$ saturated fat $-\mathrm{r} \cdot 3 \mathrm{r} \triangle \mathrm{p}$ plyunsaturated fat, the quantities being expressed in $\mathrm{mg} / \mathrm{I} 00 \mathrm{ml}$.

Diets also have an effect on other blood constituents. The content of blood urea can be shown to be related to the protein intake, and that of blood sugar fluctuates throughout the day under the influence of insulin and other hormones and is related to the time and carbohydrate content of the last meal. Similar fluctuations also occur with serum potassium and phosphorus.

A marked diurnal variation is seen in the concentration of some constituents, such as non-esterified fatty acids and serum iron, whereas no perceptible diurnal variation occurs with other constituents, such as serum electrolytes (Fawcett $\&$ Wynn, 1956). The variations in serum iron content have perhaps been most studied since they were discovered 20 years ago by Vahlquist (I94I). He showed that, in males, the serum iron content was at its highest, $135 \mu \mathrm{g} / 100 \mathrm{ml}$, at 8 a.m., falling to a low level of $100 \mu \mathrm{g} / 100 \mathrm{ml}$ at $6 \mathrm{p} . \mathrm{m}$. Similar findings have been reported by others and the subject has been reviewed by Hamilton, Gubler, Cartwright \& Wintrobe (1950). The diurnal swing is a normal finding and is diminished or absent in various haematological disorders when there is an increased iron turnover (Paterson, Marrack \& Wiggins, I953).

As well as the time of day, the time of year has an effect. Seasonal variation in haemoglobin levels has been studied and reviewed by Coulthard (I958), who worked among a prison population and showed that there was an annual cycle of haemoglobin values. The mean haemoglobin value of the population was $15.5 \mathrm{~g} / 100 \mathrm{ml}$ in 
February, and declined slowly to a low value of $\mathrm{I}_{5} \mathrm{~g} / 100 \mathrm{ml}$ by the following December. Rather similar results have been reported by Cullen (1956), Lippincott (1927) and Bratt (1938). Another prison population was studied by Thomas, Holljes $\&$ Eisenberg (196r) who measured serum cholesterol values. They found that the value for twenty-four white prisoners was highest in December and January (mean level $260-265 \mathrm{mg} / \mathrm{I} 00 \mathrm{ml})$ and lowest in late spring and early autumn (2I 5-2 I6 mg/ I00 $\mathrm{ml}$ ).

The extraordinary effects of posture on plasma volume have been shown by Fawcett \& Wynn (1960). They examined the same subjects lying down and ambulant and showed that ${ }_{5} \mathrm{~min}$ after rising, the haematocrit and plasma protein levels rose by an amount corresponding to a $10 \%$ change in plasma volume. After 15 min lying down, the haematocrit and plasma protein had fallen by about two-thirds of this amount and the restoration of plasma volume was complete after $\mathrm{I} h$.

\section{Analytical variation}

Since the determination of a blood constituent involves a sample treated by some form of analytical procedure, it follows that the total variance in the results will include the analytical variance as well as the inter-sample variance. For this reason, a study of analytical variance is extremely relevant to the subject of normal variability. Several such studies have been made, and they can be divided into two main classes. Every laboratory from time to time carries out internal checks on the consistency of its results, for example when introducing a new analytical method, by performing replicate analyses on unknown samples or by using standardized specimens. The results of these internal checks are often not published and what level of precision a laboratory accepts as satisfactory is largely a matter of choice.

Agreement between different laboratories has been studied on several occasions (Belk \& Sunderman, I947; Shuey \& Cebel, 1949; Henry, 1952; Wootton \& King, I953; Wootton, 1956). In general, material such as an inorganic solution or a large volume of serum, liquid or freeze-dried, has been subdivided and sent to a number of laboratories for simultaneous analysis. In every test reported, the collected results when compared have been in very poor agreement and sometimes the variance has been ludicrously high. Table 3 shows the results of such a test in which the

Table 3. Comparison of the results from thirty-six laboratories in which an inorganic solution was analysed

\begin{tabular}{|c|c|c|c|c|}
\hline Constituent & $\begin{array}{c}\text { Known } \\
\text { concentration } \\
\text { in solution }\end{array}$ & $\begin{array}{l}\text { Mean of } \\
\text { values } \\
\text { reported }\end{array}$ & $\begin{array}{c}\text { Coefficient } \\
\text { of } \\
\text { variation }\end{array}$ & $\underset{2 \mathrm{SD}}{\operatorname{Mean}} \pm$ \\
\hline Calcium (m-equiv./1.) & $5 \cdot 0$ & $5 \cdot 0$ & $8 \cdot 5$ & $4 \cdot I-5 \cdot 8$ \\
\hline Chloride (m-equiv./1.) & $9 \mathrm{I}$ & 93 & $5 \cdot 7$ & $83-103$ \\
\hline Sodium (m-equiv./1.) & I 54 & $I_{44}$ & $7 \cdot 4$ & $122-166$ \\
\hline Potassium (m-equiv./1.) & $5 \cdot 0$ & $5^{\circ} 0$ & $10 \cdot 0$ & $4.0-6.0$ \\
\hline Phosphate (mg/roo ml) & $3 \cdot 1$ & $3 \cdot 3$ & 20.7 & $I \cdot 9-4 \cdot 6$ \\
\hline Glucose $(\mathrm{mg} / \mathrm{roo} \mathrm{ml})$ & 255 & 255 & $10 \cdot 8$ & $186-324$ \\
\hline Urea $(\mathrm{mg} / 100 \mathrm{ml})$ & I I 2 & 105 & $26 \cdot 3$ & $50-160$ \\
\hline Uric acid $(\mathrm{mg} / 100 \mathrm{ml})$ & $3 \% 7$ & $3 \cdot 0$ & $2 I^{\prime} 4$ & $1 \cdot 7-4 \cdot 3$ \\
\hline
\end{tabular}


material circulated was an inorganic solution containing a known amount of the constituents listed. Usually the mean of all the results submitted is acceptably close to the amount known to be present in the solution but the coefficients of variation are very large. The mean \pm 2 standard deviations indicates the range within which a sample result might fall if the sample was sent at random to any one of the laboratories concerned. This range was so large that it obviously cannot apply to the results from an individual laboratory, for if it did, small changes of the order described in the previous sections would not be discerned. One is therefore forced to the conclusion that the intra-laboratory differences are very much larger than the analytical uncertainty within a single laboratory, and when studies have been made of these two effects independently, this conclusion was confirmed. It appears, therefore, that differences in the absolute values reported between laboratories must be treated with great caution although the relative effect of disease or other factors is much more likely to be reproduced. It is only fair to say that, since surveys of this type have been published, there is now a much greater awareness of the problem and standard serums are now available by which the absolute values of a laboratory may be checked. It is probable that the results today would be very much better if the surveys were repeated.

\section{Conclusions}

When normal individuals are examined, there is a variation in the level of various blood constituents. The variation is caused by a number of factors, some of which are peculiar to the individual. Other factors operate on the individual; they include his age and sex, the time of day and season of the year, the diet and geographical location of the individual and his posture and activity immediately before the sample is drawn. In addition, there is a large component of variance added by the analytical laboratory. If, as seems likely, it will become increasingly important to pick up minimum deviations from normality as the first signs of disease, then much closer attention must be paid to these factors. Even so, there is a limit to the amount by which individual variation can be reduced, but any reduction will improve our ability to detect small deviations from the normal.

My thanks are due to Dr J. D. Pryce for helpful discussions and for allowing me to use some of his unpublished data.

\section{REFERENCES}

Belk, W. P. \& Sunderman, F. W. (1947). Amer. F. clin. Path. 17, 853 .

Bratt, J. F. (1938). Acta med. scand. 97, 365 .

Bronte-Stewart, B. (I96I). In Recent Advances in Human Nutrition [J. F. Brock, editor.] London: Churchill.

Bronte-Stewart, B., Keys, A. \& Brock, J. F. (I955). Lancet, 269, I I03.

Coulthard, A. J. (1958). Clin. chim. Acta, 3, 226.

Cullen, R. (1956). Irish F. med. Sci. 370, 467.

Fawcett, J. K. \& Wynn, V. (1956). Brit. med. J. ii, 582 .

Fawcett, J. K. \& Wynn, V. (1960). F. clin. Path. 13, 304.

Gaddum, J. H. (1945a). Nature, Lond., 156, 463.

Gaddum, J. H. (1 $945 b)$. Nature, Lond., 156, 747. 
Hald, P. M., Heinsen, A. J. \& Peters, J. P. (1947). F. clin. Invest. 26, 983.

Hamilton, L. D., Gubler, C. J., Cartwright, G. E. \& Wintrobe, M. M. (1950). Proc. Soc. exp. Biol., N.Y., 75, 65 .

Henry, R. J. (r952). Clin. Chem. 4, 4.

Howland, W. S., Zucker, M. B. \& Clifton, E. E. (1957). Surg. Gynec. Obstet. 105, 529.

Josephson, B. \& Dahlberg, G. (1952). Scand. F. clin. Lab. Invest. 4, 216.

Karvonen, M. J., Pekkarinen, M., Metsala, P. \& Rantanen, Y. (I96r). Brit. J. Nutr. 15, 57.

Keys, A. (1956). F. chron. Dis. 4, 364.

Keys, A., Anderson, J. T. \& Grande, F. (1957). Lancet, 273, 959.

Keys, A., Karvonen, M. J. \& Fidanza, F. (1958). Lancet, ii, 175.

Keys, A., Kimura, N., Kusukawa, A., Bronte-Stewart, B., Larsen, N. \& Keys, M. H. (1958). Ann. intern. Med. $\mathbf{4 8}, 8_{3}$.

Keys, A., Mickelsen, O., Miller, E. v. O., Hayes, E. R. \& Todd, R. L. (1950). F. clin. Invest. 29, r 347.

King, E. J. \& Wootton, I. D. P. (1956). Micro-analysis in Medical Biochemistry, 3rd ed. London: Churchill.

Kornerup, V. (1950). Arch. intern. Med. 85, 398.

Lippincott, L. S. (1927). F. Lab. clin. Med. 12, 679.

Paterson, J. C. S., Marrack, D. \& Wiggins, H. S. (1953). F. clin. Path. 6, ro5.

Pryce, J. D. (r96o). Lancet, ii, 333.

Scott, E. M. (1960). F. clin. Invest. 39, 1176.

Shuey, H. E. \& Cebel, J. (1949). Bull. U.S. Army med. Dep. 9, 799.

Thomas, C. B., Holljes, H. W. D. \& Eisenberg, F. F. (196r). Ann. intern. Med. 54, 413.

Vahlquist, B. C. (194I). Acta Paediat., Uppsala, 28, suppl. 5.

Winters, R. W., Graham, J. B., Williams, T. F., McFalls, V. W. \& Burnett, C. H. (1958). Medicine, 37, 97.

Wootton, I. D. P. (1956). Clin. Chem. 2, 296.

Wootton, I. D. P. \& King, E. J. (I953). Lancet, 264, 47 O.

Wootton, I. D. P., King, E. J. \& Smith, J. M. (195 I). Brit. med. Bull. 7, 307.

\section{Individual variation in the lipid transport system}

\section{By Robert E. Olson, Department of Biochemistry and Nutrition, Graduate School of Public Health, University of Pittsburgh, Pittsburgh, $\mathrm{Pa}$}

The systems responsible for the transport of lipids in the animal body show great variation between and within different species of the animal kingdom. Even in the normal human subject the individual variations are impressive, the range of variation in concentration of serum lipids being considerably larger than that for glucose, amino acids, creatine, or serum albumin. As in all biological variation, the variation in the lipid transport system is a product of both genetic and environmental factors. The multi-enzyme systems concerned with the transformations of lipids and lipoproteins in animal tissues are, like all enzymes, under genetic control. Their rates of formation and breakdown, under normal conditions, are sufficiently variable to produce variation in their concentration, and hence in the steady-state concentration of intermediates and products, many of which appear in the plasma. Under pathological conditions the absence of one or more of these enzymes may produce a gross abnormality of lipid transport. In addition to these endogenous variables it has now been clearly established that the lipid transport system responds dramatically to nutritional factors, not only in the sense of transient changes in lipid level as a function of alimentation but also in the sense of long-term adaptation of fasting levels of serum lipids and lipoproteins to habitual nutritional intakes. 